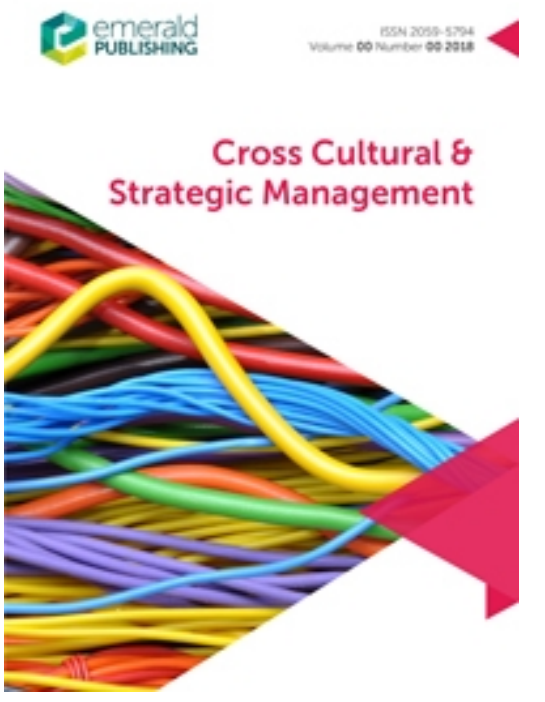

\title{
Micro-Foundations of Small Business Internationalization: Introduction to the Special Section
}

\begin{tabular}{|r|l|}
\hline Journal: & Cross Cultural \& Strategic Management \\
\hline Manuscript ID & CCSM-04-2020-0100 \\
\hline Manuscript Type: & Research Paper \\
\hline Keywords: & $\begin{array}{l}\text { Small business, SMEs, Internationalization, Entrepreneur, Personality, } \\
\text { Micro-foundation }\end{array}$ \\
\hline
\end{tabular}

\section{SCHOLARONE ${ }^{\mathrm{m}}$ \\ Manuscripts}


Johanna Vanderstraeten, Ellen Loots, Anais Hamelin, Arjen van Witteloostuijn

\title{
Micro-Foundations of Small Business Internationalization
}

\section{Introduction to the Special Section}

\begin{abstract}
Purpose: We introduce and summarize the selected papers of the Special Section on the "Micro-Foundations of Small Business Internationalization".

Design: We briefly summarize the state-of-the-art of the literature regarding the microfoundations of small business internationalization. Then, we summarize the selected papers of the Special Section, highlighting their main contributions. We end with suggesting future research avenues.
\end{abstract}

Finding: We move beyond the usual suspects such as gender, education and experience to bring together internationalization studies that open up the individual lens to small business internationalization. To do so, we selected papers examining deeper-level behavioural and psychological constructs impacting the internationalization process, going from internationalization intention to internationalization behaviour, and eventually leading to internationalization performance.

Originality/value: We stress the importance of the entrepreneur as a person to better understand small business internationalization. We address the current lack of attention attributed to psychological and behavioural drivers (e.g., motives, attitudes, ambitions and aspirations) throughout the internationalization process, and we urge future researchers to further develop this research stream.

\section{Key words}

Small business; SME; Internationalization; Entrepreneur; Personality; Micro-foundation 


\section{The aim and scope of the Special Section}

Long before the upsurge of entrepreneurship research, Edith Penrose pointed to the difficulty of including "entrepreneurship" into a general economic theory of firm growth because of its close association with the personality and temperament of the individuals involved (Penrose, 1959). In this Special Section, we put central those individuals who, so we argue, are of interest to better understand small businesses' growth and, in particular, small businesses' internationalization. Recent evidence suggests that small businesses show differences in growth patterns while appearing similar in terms of organizational and environmental characteristics, such as size, sector, governance and access to finance (Hamelin, 2013; Hurst and Pugsley, 2011). Such findings are at the centre of a longstanding discussion in the entrepreneurship literature (Carland et al., 1984) about whether and how an entrepreneur's individual characteristics influence firm outcomes, including internationalization (e.g., Siepel et al., 2019).

The individual characteristics examined in growth studies include aspects such as gender, educational background and personality traits (Baron, 2000; Baum et al., 2014; Boone et al., 1996; Brandstätter, 2011; Lee and Tsang, 2001; Wijbenga and van Witteloostuijn, 2007; Zhao et al., 2010). For example, it has been demonstrated that aspects such as gender (Verheul and Van Mil, 2011), social background, education and experience (Cassar, 2006; Guzmán and Santos, 2001) have a direct impact on an entrepreneur's growth ambitions. Interestingly, a number of empirical studies dive deeper into psychological and behavioural aspects, such as an entrepreneur's attitudes, motives and ambitions, and show, among other things, that growth attitudes and intentions are important predictors of subsequent firm growth (Davidsson et al., 2006; Stam and Wennberg, 2009).

In this Special Section, we follow this research stream and move beyond the usual suspects such as gender, education and experience to bring together internationalization 
studies that open up the personal lens. In this way, we further develop the state-of-the-art on the psychological and behavioural drivers (e.g., motives, attitudes, ambitions and aspirations) of small businesses internationalization. Indeed, whereas the literature has, for example, established that growth aspirations influence expected firm growth (Cassar, 2006; Wiklund and Shepherd, 2003), the specificities and determinants of entrepreneurs' underlying psychological and behavioural aspects impacting small business internationalization are far less known. For example, it has been argued that growth-oriented entrepreneurs have higher intrinsic motivations residing within specific needs such as those for personal development (Guzmán and Santos, 2001); whether (or not?) there is a distinction between the intrinsic motivations of entrepreneurs oriented towards the domestic market only, and those seeking for international expansion, is still to be discovered. This is exactly what we explore further within the scope of this Special Section, published in volume 27, number 1 of this journal, and supplemented with Haapanen (2020).

Overall, the papers of our Special Section address the paucity of studies on individuals' psychological and behavioural aspects in the field of internationally growing small businesses. As such, more generally, we respond to the need for a deeper understanding of micro-foundations to explain small business international competitiveness and performance (Abell et al., 2008; Coff and Kryscynski, 2011), in the tradition of what became known as behavioural strategy (Powell et al., 2011). We thus explicitly put the entrepreneur (and her / his team) in the central position, and try to answer the question: "What makes that some entrepreneurs (want to) explore and exploit international markets while others do not, apart from their businesses' organizational features and perceived business opportunities abroad?" 


\section{Current state-of-the-art of the micro-foundations of small business internationalization}

The study domain of small business internationalization - also called International

Entrepreneurship (IE) - is incredibly large with many different themes and subthemes (Jones et al., 2011). Rightfully, the three levels of analysis (the entrepreneur, the firm, and the environment) are recurring cornerstones in IE studies (e.g., Keupp and Gassmann, 2009; Mejri and Umemoto, 2010), with more and more studies stressing the importance of a contingency view where two or more levels of analysis are studied in an integrative manner (Kiss et al., 2012; De Clerq et al., 2012). Although such more complex models (e.g., Child and Hsieh, 2014; Handrito et al., 2020) are, without any doubt, very useful to further advance research in the field of IE, the constructs taken into account in IE studies at the level of the entrepreneur tend to neglect deeper-level psychological and behavioural aspects (Handrito et al., 2020).

That is unfortunate, in particular because earlier personality studies do portray national differences. Jung et al. (2001) and Thomas and Mueller (2000), for example, portray country differences when probing into concepts such as entrepreneurial self-efficacy, internal locus of control and risk-taking propensity. They find that perceptions of entrepreneurial self-efficacy are lower in collectivistic nations than in individualistic ones (Jung et al., 2001), and argue that in countries culturally distant from the United States, an entrepreneur's internal locus of control and risk-taking propensity are lower (Thomas and Mueller, 2000). Given that entrepreneurial self-efficacy is positively related to entrepreneurial intentions and actions in a highly individualistic country (Jung et al., 2001) it seems that entrepreneurial activities such as firm internationalization thrive more in some countries than in others. Whether this is indeed the case, however, is yet to be discovered.

When probing deeper into studies focusing on the relationship between individual aspects and internationalization, it is apparent that the first studies in this domain only started 
to emerge around the mid-2000s (Jones et al., 2011). This is much later than general entrepreneurship research, including that with a behavioural flavour, Schumpeter (1912/1988) already advocating at the beginning of the twentieth century for a central place of the entrepreneur in economic development studies. Overall, we can roughly subdivide small business internationalization studies into the chronology of the internationalization process, starting from pre-internationalization and internationalization intention to internationalization behaviour, and ending up with research on internationalization performance (see, e.g., Jones and Coviello (2005) who adopt a similar process view).

For example, Casillas and Acedo (2013) show in a review study that education abroad (e.g., Bloodgood et al., 1996; Reuber and Fisher, 1997) or a global vision (e.g., Oviatt and McDougall, 1994) are determinants of internationalization speed, and Zuchella et al. (2007) explain that prior international experience nurtured in family firms drives early firm internationalization. Jones and Coviello (2005) pinpoint that aspects such as the entrepreneur's tolerance for ambiguity or flexibility, need for achievement, risk perception or risk tolerance all influence internationalization intention. In an extensive review study on IE, Keupp and Gassmann (2009) show that 25 per cent of the studies in the domain focus on the impact of socio-cognitive or demographic properties of owners / managers on the propensity to internationalize. Even though this seems relatively high, the attention attributed to individual aspects is surprisingly low in specific sub-domains of IE, and studies on deeperlevel psychological and behavioural aspects are clearly underrepresented.

More specifically, there is a clear lack of studies focusing on the impact of the entrepreneur's characteristics as an antecedent of an SME's entry mode. ${ }^{1}$ Bruneel and De Cock (2016), for example, show in their systematic literature review on an SME's entry mode

\footnotetext{
${ }^{1}$ In this paper, please note that we employ the terms SME and small business interchangeably.
} 
that although 81 per cent of the studies focus on antecedents, almost all attention goes to environmental uncertainty and asset specificity. They only found one study that focused on the individual level; Pinho (2007) showed that the entrepreneur's ability to innovate and its international experience are positively associated with an equity-based entry mode. This lack of attention to the individual level does not only contradict general small business and entrepreneurship literature (Shepherd, 2011), but also ignores SME internationalization research (Oviatt and McDougall, 2005) where it is argued that the manager / owner is in the centre of the entrepreneurial decision-making process (Bruneel and De Cock, 2016; Peschken et al., 2016).

The second remark relates to the lack of research on deeper-level psychological and behavioural aspects in relation to the pre-internationalization phase. Although the extant body of knowledge does recognize the importance of individual aspects such as the entrepreneur's proactiveness and risk or opportunity perceptions (e.g., Acedo and Galán, 2011), deeper-level constructs such as the entrepreneur's motivational system are under-researched in relation to the intention to internationalize. This is unfortunate, in particular because studies such as those El Shoubaki et al. (2019) and Hermans et al. (2017) reveal that to advance our understanding of company goals and growth, studies need to integrate insights on entrepreneurial motives. A sole focus on human capital dimensions is insufficient (El Shoubaki et al., 2019). In the IE domain, Handrito et al. (2020) reveal that an entrepreneur's implicit need for achievement is associated with an SME's internationalization performance. Given that motivational dispositions and specifically deep-rooted implicit needs energize individuals and predict stable, long-term behaviour (Schultheiss and Brunstein, 2010; Slabbinck et al., 2018), it goes without saying that studies about such deeper-level psychological and behavioural constructs in relation to internationalization intention are badly needed. 
In sum, even though the body of knowledge on the pre-internationalization phase thus shows that individual aspects such as risk perception (e.g., Acedo and Jones, 2007; Shrader et al., 2000), higher education levels (e.g., Amorós et al., 2016) or international experience (Child and Hsieh, 2014) impact the decision to internationalize and its timing, the specificities on the impact of such individual aspects in specific sub-domains are under-researched (e.g., Bruneel and De Cock, 2016) and the number of studies on deeper-level psychological and behavioural aspects is still surprisingly low (Acedo and Florin, 2006; Geh, 2010; Peschken et al., 2016).

When we turn our attention to actual internationalization behaviour, it is apparent that a large number of studies in the IE domain focus on patterns and processes of internationalization (Jones et al., 2011). Within this group of studies, however, only a few acknowledge the importance of individual-level aspects. Indeed, although a large number of IE studies examine if and how the entrepreneur's demographic and socio-cognitive characteristics favour early internationalization (Keupp and Gassmann, 2009), the interlinkages between such individual elements and actual firm internationalization behaviour are under-researched.

One notable exception is Child et al. (2017), who examine three distinct international business models and show that the decision-maker's international experience predicts the adopted international business model. For example, they find that decision-makers with previous international business experience tend to adopt an ambidextrous explorer business model, which is a "business model [that] combines exploration and exploitation, though with a much greater investment in exploration than the other models" (Child et al., 2017, p. 670). Another exception is Rialp et al. (2005), who stress the importance of a firm's internationalization capabilities. They define internationalization capabilities as "an unobservable or 'invisible' strategic asset mostly characterized by scarce home-based path 
dependencies but high levels of tacitness and causal ambiguity in its accumulation process" (p. 161), and reveal that the entrepreneur's human capital drives such capabilities.

When we relate these insights to Mejri and Umemoto's (2010) knowledge-based model of SME internationalization, in which experiential knowledge is put central throughout the internationalization process, one can argue that the development of experiential knowledge - which is an individual-level constructs comprising network, cultural and entrepreneurial knowledge - starts in the pre-internationalization phase, and is further strengthened during the subsequent internationalization process (Mejri and Umemoto, 2010). Again, in this viewpoint, individual aspects such as personal experiential knowledge are thus prevalent throughout the entire internationalization process.

The usefulness of a knowledge-based approach is also implicitly embedded in Perks and Hughes' (2008) study, who argue that it is rather the entrepreneurs' connections to customers, and their tacit knowledge, vision and product-service complexity that define whether or not the entrepreneur decides to internationalize. Indeed, by extending these insights to Mejri and Umemoto's (2010) knowledge-based internationalization model, we argue that Perks and Hughes' (2008) strategy-related aspects are underpinned by experiential knowledge development throughout the entire internationalization process: Thanks to experiential knowledge development, the entrepreneur is able to further develop, e.g., its connections to customers and product-service complexity throughout the entire internationalization process.

Finally, when turning our attention to internationalization performance studies, it turns out that a large number of IE studies examine the association between organizational issues and internationalization performance (Jones et al., 2011). This is much less the case for studies acknowledging a direct association between individual-level aspects and internationalization performance. Notable exceptions are Ruzzier et al. (2007) and Handrito et 
al. (2020), who show that the entrepreneur's risk perception and international orientation influence the firm's degree of internationalization (Ruzzier et al., 2007), and unravel the relationship between the entrepreneur's implicit need for achievement, risk perception and internationalization performance (Handrito et al., 2020). More specifically, the latter show that the highest level of internationalization performance is achieved by entrepreneurs scoring high on implicit need for achievement and who perceive risks as very high.

In sum, these results suggest that although individual-level aspects such as the manager's global vision (Johnson, 2004) or international experience and knowledge (Terjesen and Elam, 2009) are often taken into account in relation to internationalization decisions (Terjesen et al., 2016), direct associations with internationalization performance are examined to a much lesser extent. This does not seem to be justified, in particular not in relation to deeper-level psychological constructs which define, as discussed above, long-term behaviours and outcomes (Schultheiss and Brunstein, 2010), such as internationalization performance (Handrito et al., 2020).

\section{The Special Section contents}

The articles in the Special Section advance our knowledge on the individual drivers of the internationalization process of small businesses. We purposefully selected papers that take account of behavioural and psychological constructs such as motives, attitudes, ambitions or aspirations to advance our lack of knowledge in this domain. Table 1 provides an overview of the Special Section's contributions.

[Insert Table 1 about here]

The first paper by Bowen (2020) examines the motives of SME internationalization in a comparative study of Wales and Brittany. The study allows us to gain a comprehensive 
understanding of the barriers that either favour or prevent firms to internationalize, and more specifically how variables at different levels (i.e., individual, firm and environment) interact to influence the motives to internationalize. Specifically, the fact that the author positions the underlying motives to internationalize as being proactive or reactive (Czinkota \& Ronkainen, 2006; Hollensen, 2014) of already internationalizing entrepreneurs, and that he argues that an entrepreneur's attitude to internationalization can be active or passive depending on underlying personal, firm and environmental variables, is of interest for this Special Section. All in all, the paper can be positioned as a pre-internationalization study.

Although not explicitly referred to, the author relies on contingency theory to argue that different levels of analysis jointly influence an entrepreneur's motives and attitudes to internationalize. He adopts a mixed methods approach, and focuses on a single industry (food and drinks) in two specific regions (Wales and Brittany) to minimize environmental variation. This allows him to not only probe into the web of underlying factors towards (non)internationalization, but also to explicitly take into account cultural and environmental differences between these regions. He first distributed an online questionnaire to capture factors impacting the firm's internationalization status (i.e., exporting or not exporting). In a second phase, he conducted 37 semi-structured interviews to further probe into the questionnaire findings. To do so, he separately analysed the data of the two earlier mentioned groups: Exporting and non-exporting SMEs. The choice of separating the sample firms according to their internationalization status (exporting versus non-exporting firms) in the qualitative study allows the author to explore whether motives and attitudes to internationalization vary in function of the internationalization status of the firm. In addition, the assumed symmetry between the perceived drivers and inhibitors of firms in a preinternationalization phase, and of those that already (cautiously) started to internationalize, is 
questioned. Overall, this mixed method approach allows the author to obtain a holistic view of the underlying factors of SME internationalization.

When probing into the findings of the paper, it is apparent that Bowen's quantitative results point to a mixture of proactive and reactive motives for internationalization. Proactive motives turn out to be, amongst others, an international growth strategy and growth opportunity awareness, whereas reactive motives are underpinned by being risk averse. Moreover, the results unravel differences in both motives and the conditions to internationalize across the two cultural contexts studied: Wales and Brittany. These findings are further investigated in the qualitative phase of the study. Here, he explicitly subdivides the data coming from internationalizing and non-internationalizing firms. He observes that already internationalized firms subdivide the motives to internationalize into three motivation themes: Reactive, proactive, or mixed. Interestingly, for non-exporters, Bowen distinguished three underlying attitudes towards internationalization: (1) No desire for internationalization, (2) passive towards internationalization, and (3) an active desire for internationalization that failed. Regarding the regional differences (Wales versus Brittany), he observed that environmental conditions are perceived as more favourable in Brittany, where less barriers to internationalize were listed. Here, the desire to internationalize also turned out to be greater.

Overall, the findings of this paper explicitly show that the three levels of analysis (entrepreneurial, firm and environmental) play a significant role in shaping the motives for and attitudes to internationalization. Specifically, it turned out that environmental conditions lay the foundations for many firm attitudes to internationalization. Moreover, the results underline that although firms of all examined characteristics have the ability to internationalize, internationalization is more likely to occur when the firm adopts a more proactive attitude towards internationalization. Finally, the results also underline that the local 
culture / ecosystem is an important driver of internationalization. It echoes, in a novel manner, the stylized fact of observed differences in small business internationalization across Europe.

The second paper, written by Evans, Ermilina and Salaiz (2020), scrutinizes the role of reciprocity in the internationalization of social enterprises. According to the authors, the question of how internationalization occurs within social enterprises (SEs) has been overlooked in small business and entrepreneurship studies, while this question is particularly salient because many SEs address global problems. Social enterprises generally seek to simultaneously address two goals: The achievement of a socially desirable outcome, combined with financial self-sufficiency (Sharir and Lerner, 2006; Battilana and Lee, 2014). They do so as non-profit, for-profit or hybrid forms of organization (Mair and Marti, 2006). Until today, internationalization successes in SEs have been ascribed to the characteristics and networks of the owners, as well as the transposability of various resources, including financial, logistic and operational resources (Hutchinson et al., 2006).

In their quest for the micro-foundations of small firm internationalization, the authors rely on social exchange theory (SET) in order to explain the role of reciprocity as a key component within the internationalization process of SEs. As one of the central pillars in SET, reciprocity refers to the mutually beneficial exchange between partners (Gouldner, 1960). Recognizing the numerous transactional relationships in social life, SET has found reciprocity to be a crucial component of mutual exchange and commitments, also in organizational studies (Cropanzano and Mitchell, 2005; Gouldner, 1960). Relying on SET and reciprocity, Evans and her colleagues theorize that the internationalization process of small businesses with a social purpose could be distinct from that of other enterprises, because reciprocity leads to faster rates of embeddedness and knowledge exchange with local stakeholders.

As such, the article suggests that the theoretical framework of the Uppsala internationalization model (Johanson and Vahlne, 1977) may be less applicable to SEs. 
Rooted in the behavioural theory of the firm (Cyert and March, 1963; Penrose, 1959), the Uppsala model has been the result of an empirical study of how Swedish manufacturers entered foreign markets, revealing the sequential steps in the process. It has become a prominent conceptual tool for the interpretation of internationalization processes, which, since its inception in 1977 , has been regularly revisited by accounting for new perspectives and research results (e.g., Johanson and Vahlne, 2009; Vahlne and Johanson, 2013, 2017). As a dynamic theory of the internationalization process, the Uppsala model regards internationalization as a result of an incremental learning process: Enterprises expand incrementally from one psychic close market to the next one, and, by learning and building up market knowledge and resources, they cope with the risks and uncertainties commonly associated with the expansion into foreign markets (Johansen and Vahlne, 1977).

Evans and her colleagues derive from the Uppsala model the proposition that the lack of knowledge about foreign markets makes up the largest hurdle in firms' incremental internationalization processes, and they argue that social enterprises are able to bypass the obstacles and incrementalism traditionally ascribed to internationalization by means of reciprocity. Based on their theorizing, the authors suggest that social enterprises may be capable of internationalizing more swiftly compared with organizations lacking the social purpose, and they elicit how the social mission can be a driver of the internationalization process (cf. Kalinic and Pater, 2013). Hence, so they argue, the social orientation of a SE is an "essential tool for establishing effective connections with local stakeholders via positive reciprocal exchanges" (p. 77), which they illustrate with two examples (one is the Jibu clean water project in Africa; the other one the Educate Girls project in Rajasthan, India): When SEs enter a foreign market, a social exchange process is set in motion. Bringing a good or service with social properties into a new market installs a process of reciprocity, which originates in an affective commitment and increased levels of trust (e.g., Bishop and Scott, 
2000) between the SE and local stakeholders. Evans and her colleagues argue that such reciprocal relationships will lead to a local embedding of the SE that exceeds the pace with which any other enterprise would succeed in doing so. Once embedded in the local social structure, SEs will not only benefit from economies of time, but also from a greater likelihood of knowledge exchange (Uzzi, 1997), as well as higher levels of commitment and cooperative behaviour. In contrast to internationalizing enterprises that are not involved in reciprocal relationships, so Evans and her colleagues argue, SEs will be less affected by information deficiencies because of the established trust.

The variance of a SE's internationalization success is then dependent on the extent to which this process of reciprocity is effectuated within a local social community with its specific values and norms. The authors develop a number of propositions based on Hofstede's (1991) dimensions of national culture. Firstly, in collectivist countries (cf. Hofstede, 1991), the accelerated rate of embeddedness through reciprocity will be greater than in individualist countries. Also, secondly, a country's level of femininity (compared with masculinity, cf. Hofstede, 1991) affects the rate of SE internationalization, with feminine cultures more prone to relational values thus reciprocity. Thirdly, cultures with weak uncertainty avoidance are more comfortable with the unknown (Hofstede, 1991), and thus likely to be less suspicious to the value propositions of SEs.

Taken together, while social missions are the very reason why SEs internationalize, Evans and her colleagues conceptualize of an organization's social orientation as a valuable intangible asset that can ease the process of internationalization through reciprocity. Such a take on small firm internationalization is important, not only because it is essential to understand the behaviour of SEs, which are no longer a marginal phenomenon, but also because other enterprises could benefit from establishing reciprocal relationships in foreign 
markets in order to overcome the barriers commonly associated with a lack of information or trust.

The third paper of Gundlach and Sammartino (2020) probes into individual differences within one specific entrepreneurial segment: Women entrepreneurs, a group whose social and economic importance cannot be overestimated (Holmquist and Carter, 2009). The authors compare the individual traits and attributes of women entrepreneurs with those of their female decision-making counterparts in larger organizations. As such, they pinpoint the specificities of businesswomen, and challenge the idea that the "the ideal entrepreneur is typically represented as 'a risk-taking innovator who proactively exploits international growth opportunities' (Welch et al., 2008, p. 116)”, cited in Gundlach and Sammartino (p. 93). Gundlach and Sammartino explain that the criticists of this definition argue that its inherently masculinist orientation does not do justice to female characteristics of entrepreneurship. For this, studies probing into differences of female entrepreneurs compared to female employees are necessary. Gundlach and Sammartino follow this argument and stress that a focus on women allows us to understand deeper-level differences within one gender type, as opposed to further reinforcing male dominance in the field of entrepreneurship.

To do so, the authors set out a survey among Australian businesswomen. They gathered data on 186 female entrepreneurs (business owners) and 137 decision-making employees. Of the female entrepreneurs, 130 were already internationally active, as compared to 112 of the female decision-making employees. They employed independent samples $t$-tests to compare small business owners with decision-making employees, and internationalizing with non-internationalizing businesswomen on personality traits, perceived self-efficacy and perceived barriers to internationalize. 
The authors find that proactiveness is higher among small business owners, but that contrary to the expectations - decision-making employees score higher on tolerance for ambiguity and management self-efficacy. Interestingly, tolerance for ambiguity turned out to be significantly higher for businesswomen who were already engaged in international activities, compared to those who were only focusing on the domestic market. This difference did not hold for business owners, where no statistical difference between internationalizing and non-internationalizing business owners on individual traits and attributes could be found. Finally, Gundlach and Sammartino portrayed that decision-making employees perceive resource barriers to internationalize as significantly lower than small business owners. In addition, they found significant and consistent differences of five types of internationalization barriers between internationalizing and non-internationalizing businesswomen: Perceived knowledge, resource, procedure, exogenous and personal barriers. These differences remained stable (albeit not always significant) for the sub-groups of small business owners and employees only.

When probing deeper in their findings, it is apparent that there are no statistical differences on personality traits and attributes between internationalizing and noninternationalizing female business owners. This seems to suggest that for female business owners, other explanations need to be discovered with regard to the decision to internationalize. Perceived barriers to internationalize seem to be a good candidate to do so. Such barriers turned out to be significantly lower for small business owners already internationally active compared to small business owners not yet internationally active. This seems to suggest that once female small business owners are internationally active, they are more flexible to travel internationally, and have more confidence in pursuing international business opportunities. 
Taking all results together, Gundlach and Sammartino propose that the choice to internationalize a small business is dependent upon the owner's perceptions about the firm's available resources, knowledge and networks. Specifically related to individual-level constructs, they propose that the owner's perception about personal self-efficacy in the internationalization domain defines the decision whether or not to internationalize. This seems to suggest that although firm and environmental variables cannot be neglected in the decision to internationalize, that individual constructs such as personal self-efficacy should be taken into account as well in a study on small business internationalization.

Finally, in the fourth paper, Haapanen, Hurmelinna-Laukkanen and Puumalainen (2020) acknowledge that similar levels of internationalization can be achieved through different pathways. In their contribution to the Special Section, the authors empirically investigate how attributes at both the manager's level (dynamic capabilities) and the team level (consensus) jointly yet differently impact internationalization, by means of a configurational (QCA) approach (Ragin, 2014). The management and international business literatures have articulated the importance of a manager's knowledge, skills and motivation as drivers of international expansion (e.g., Dimitratos et al., 2011), as well as the international experience of a firm's top management team (TMT) (Hutzschenreuter and Horstkotte, 2013). Equally, the literature states that some level of consensus within the team is needed to achieve such strategic expansion goals (Teece, 2007). Haapanen and his colleagues bring together those insights in their study of the relationship between dynamic managerial capabilities and the strategic consensus within the TMT in connection to those capabilities, on the one hand, and different stages of the internationalization process, on the other hand.

In line with the upper echelon perspective (Hambrick and Mason, 1984; Boone et al., 2004), the authors recognize that within-team heterogeneity may lead to positive outcomes, including various capabilities, but that it could also hamper the development of strategic 
consensus and the implementation of a firm's strategies. They posit that "TMT strategic consensus occurs when executives share their perception of the firm's current competitive standing, and based on this common understanding, are capable of making strategic decisions" (forthcoming) (Bragaw and Misangyi, 2019). As the literature remains scant with regard to how strategic consensus over different aspects of dynamic managerial capabilities regulates internationalization, Haapanen and his colleagues take up a set-theoretic method (Ragin, 2014) to study those mechanisms. In line with Augier and Teece (2009), the authors disaggregate dynamic managerial capabilities into sensing opportunities and threats, seizing opportunities, and reconfiguring capabilities in order to reveal the configurations of varying dimensions of those managerial capabilities and a TMT's strategic consensus in relation to a firm's internationalization process.

In line with, for example, Woldesenbet et al. (2012), the findings based on survey data collected from 261 TMT members within 61 firms underline that dynamic managerial capabilities are important for firm internationalization. In contrast, they also suggest that neither those capabilities, nor TMT diversity or strategic consensus in isolation are able to explain internationalization. Interesting is that a lack of TMT consensus seems to prevent firms from international stagnation when it comes with the presence of dynamic managerial capabilities; only in combination with low reconfiguration capabilities (or when a firm is incapable of changing its approach), not being able to agree on strategies at the team level is likely to generate negative results.

The contribution of the article by Haapanen and his colleagues mainly resides in bringing together manager- and team-level characteristics in order to explain firm-level internationalization, doing so through a QCA configurational bundle lens, and in revealing how nuanced the internationalization process can be, by disentangling managerial capabilities 
and TMT composition into a number of components and bring them into configurations that do work, or that do not.

\section{Future research directions}

Based on our own literature review and the contributions of the papers linked to this Special Section, six future research avenue emerge, at least. First, we started this Special Section with a little state-of-the-art review of the micro-foundations of small business internationalization literature, and urged future researchers to further attribute attention to deeper-level behavioural and psychological constructs throughout the internationalization process (e.g., Handrito et al., 2020). One way of doing so is by comparing different cultural and institutional settings. Comparative cross-context studies do not only allow us to dive deeper into the individual differences of internationally growing entrepreneurs, but also to better understand whether and how cultural and institutional contexts impact such differences (e.g., Leung and Bond, 1989; Chudzikowski et al., 2011). The comparative cross-context approach thus contributes to the clarification of how and to what extent entrepreneurs' growth aspirations, ambitions and motives interact with their willingness and openness to expand in and adjust to different regional or national contexts (e.g., Busenitz and Lau, 1996; Liñán and Chen, 2009).

Bowen and Gundlach and Sammartino both extend this idea and show that not only research in different contexts, but also studies on different groups of entrepreneurs shed light on the micro-foundations of small business internationalization. Bowen focused on examining the motives and attitudes to internationalization across internationalizing and noninternationalizing firms. As such, he challenged the idea that the internationalization of a firm is a naturally occurring phenomenon. Instead, he proposes that internationalization is, at least partially, determined the by entrepreneur's preferences, albeit combined with firm 
characteristics and environmental conditions. Gundlach and Sammartino focused on female entrepreneurs. Interestingly, they did not find statistical differences between internationalizing and non-internationalizing female business owners on typical "male" individual traits and attributes, such as proactiveness. This seems to suggest that for this entrepreneurial segment, other individual constructs lie at the basis of the decision to internationalize. Such reasoning is in line with Phan and Wright (2018), who underline "that cognition and behaviour are at the core of management research. Research at the individual, organization, and system levels of analysis ultimately starts from theories of why and how individuals make decisions to compete or cooperate to achieve their goals" (p. 179).

Second, whereas individual-level constructs, without any doubt, contribute to underpinning the decision to internationalize and the subsequent internationalization process, studies on all three levels of analysis (that is, the entrepreneur, the firm and the environment) are still needed. Gundlach and Sammartino corroborate this, in particular because they found differences regarding the perceived barriers to internationalize between internationalizing and non-internationalizing female business owners. Haapanen and his colleagues go one step further, and show that the dynamic capabilities at the manager level, strategic consensus at the team level and the performance at the firm level should be brought together into configurational sets because in isolation they fail to explain firm performance (i.e., internationalization). We urge future researchers to do so, and to not only acknowledge the importance of the individual, the firm and the environment, but also of the team, in so doing contributing to the development of comprehensive and complex models to understand the underlying psychological and behavioural aspects of small businesses internationalization.

Third, next to studying the antecedents and behaviours of such configurations (in relation to their international activities) more in depth, the interactions between TMT consensus and managerial capabilities could be scrutinized in future research as well: The 
findings of Haapanen and his colleagues already seem to suggest that dynamic managerial capabilities may lead to international development when there is no consensus within the team. Because this would call for statistical analyses, in-depth data collection on team processes in interaction with management would certainly benefit the quality of future research. Since researchers rarely have the opportunity to observe how TMTs develop strategic decisions and consensus, there is a clear lack of insights on the dynamics of this process, particularly during international expansion. We therefore call for future studies adopting a longitudinal approach.

Fourth, in line with this, Bowen's results echo the observation that growth motivation influences actual firm growth (Baum et al., 1998; 2001; Cassar, 2007; Kolvereid and Bullvag, 1996; Miner et al., 1989), and that growth motivation is, at least partially, determined by the entrepreneur's preferences, personal goals or expected consequences of growth (Bird, 1988; Carland et al., 1984; Cooper, 1993; Davidsson, 1991; Dutta and Thonhill, 2008; Herron and Robinson, 1993; Kolvereid, 1992; Wiklund et al., 2003). We urge future researchers to further unravel such specificities for internationalization, and elicit how the entrepreneur's preferences and / or personal goals influence internationalization motives and attitudes, and subsequent performance. Combining this with insights at the firm and environmental level of analysis would further bridge the three levels of analysis influencing firm growth (Felin et al., 2015), as suggested in contingency theory and adopted in IE research (see, for example, Keupp and Gassmann, 2009).

Fifth, future researchers could investigate the propositions made by Evans and her colleagues, and study how reciprocity can benefit social enterprises in the internationalization process, as well as to what extent reciprocity leads to internationalization successes, among other characteristics of the firm, the entrepreneur, and the context in which SE internationalization takes place. Reciprocity, similar to trust, is a core organizing principle, 
and reciprocated contacts might enable or constrain entrepreneurship and internationalization (Janjuha-Jivraj and Spence, 2009; Kim and Aldrich, 2005). While reciprocity as a sociocultural dynamic in entrepreneurship has regularly been studied in family and ethnic group contexts, bringing it into the SE domain and taking into account its various manifestations (Verver and Koning, 2018), is therefore a fertile avenue to go.

Sixth and finally, a final future research avenue based on Evans et al.'s conceptual reasoning is that the relationship between (international) entrepreneurship and reciprocity is far from understood - in all types of ventures, not only SEs. This is strange, as entrepreneurs are permanently facing exchange and decision processes in interaction with clients and investors; whether and how the willingness to return favours (or harm, for that matter) affects the entrepreneurial process and firm internationalization is well worth studying (cf. Cable and Shane, 1997). In this regard, micro-foundations such as reciprocity tendencies, either as a personality trait or a form of social cognition, could benefit from adequate measurement instruments suited for the (international) entrepreneurship context, possibly inspired by work in economic psychology and experimental social psychology (e.g., Berkowitz, 1968; Caliendo et al., 2012).

\section{References}

Abell, P., Felin, T., and Foss, N. (2008), "Building micro-foundations for the routines, capabilities, and performance links”, Managerial and Decision Economics, Vol. 29, pp. 489-502.

Acedo, F.J., and Florin, J. (2006), “An entrepreneurial cognition perspective on the Internationalization of SMEs", Journal of International Entrepreneurship, Vol. 4 No. 1, pp. 49-67.

Acedo, F.J., and Galán, J.L. (2011), "Export stimuli revisited: the influence of the characteristics of the managerial decision makers on international behaviour", International Small Business Journal, Vol. 29 No. 6, pp. 648-670. 
Acedo, F. J., and Jones, M. V. (2007), "Speed of internationalization and entrepreneurial cognition: Insights and a comparison between international new ventures, exporters and domestic firms", Journal of World Business, Vol. 42 No. 3, pp. 236-252.

Amorós, J. E., Basco, R., and Romaní, G. (2016), “Determinants of early internationalization of new firms: The case of Chile", International Entrepreneurship and Management Journal, Vol. 12 No. 1, pp. 283-307.

Augier, M., and Teece, D.J. (2009), "Dynamic capabilities and the role of managers in business strategy and economic performance”, Organization Science, Vol. 20 No. 2, pp. 410-421.

Baron, R.A. (2000), "Psychological perspectives on entrepreneurship: Cognitive and social factors in entrepreneurs' success", Current Directions in Psychological Science, Vol. 9, pp. 15-18.

Battilana, J., and Lee, M. (2014), “Advancing research on hybrid organizing-Insights from the study of social enterprises", The Academy of Management Annals, Vol. 8 No. 1, pp. $397-441$.

Baum, J. R., Frese, M., and Baron, R.A. (Eds.) (2014), The Psychology of Entrepreneurship, East Sussex, New York: Psychology Press.

Baum, R., Locke, E., and Kirkpatrick, S. (1998), “A longitudinal study of the relation of vision and vision communication to venture growth in entrepreneurial firms", Journal of Applied Psychology, Vol. 83 No. 1, pp. 43-54.

Baum, R., Locke, E., and Smith, K. (2001), “A multidimensional model of venture growth”, Academy of Management Journal, Vol. 44 No. 2, pp. 292-303.

Berkowitz, L. (1968), "Responsibility, reciprocity, and social distance in help-giving: An experimental investigation of English social class differences", Journal of Experimental Social Psychology, Vol. 4 No. 1, pp. 46-63.

Bird, B. (1988), "Implementing entrepreneurial ideas: The case for intention", Academy of Management Review, Vol. 13 No. 3, pp. 442-453.

Bishop, J. W., and Scott, K.D. (2000), “An examination of organizational and team commitment in a self-directed team environment", Journal of Applied Psychology, Vol. 85 No. 3, pp. 439.

Bloodgood, J.M., Sapienza, H.J., and Almeida, J.G. (1996), “The internationalization of new high-potential ventures: Antecedents and outcomes", Entrepreneurship Theory \& Practice, Vol. 20 No. 4, pp. 61-76. 
Boone, C., De Brabander, B., and van Witteloostuijn, A. (1996), “CEO locus of control and small firm performance: An integrative framework and empirical test", Journal of Management Studies, Vol. 33 No. 5, pp. 667-700.

Boone, C., Van Olffen, W., van Witteloostuijn, A., and De Brabander, B. (2004), “The genesis of top management team diversity: Selective turnover among top management teams in Dutch newspaper publishing, 1970-94", Academy of Management Journal, Vol. 47 No. 5, 633-656.

Bowen, R. (2020), "Motives to SME Internationalisation: A Comparative Study of export propensity among food and drink SMEs in Wales and Brittany", Cross Cultural \& Strategic Management, Vol. 25 No. 1, pp 51-74

Bragaw, N.A., and Misangyi, V. (2019), "Disentangling strategic consensus: Strategic consensus types, psychological bonds, and their effects on strategic climate", Academy of Management Review, In-Press.

Brandstätter, H. (2011), "Personality aspects of entrepreneurship: A look at five metaanalyses", Personality and Individual Differences, Vol. 51, pp. 222-230.

Bruneel, J., and De Cock, R. (2016), "Entry mode research and SMEs: A review and future agenda”, Journal of Small Business Management, Vol. 54 No. S1, pp. 135-167.

Busenitz, L.W., and Lau, C.M. (1996), “A cross-cultural cognitive model of new venture creation", Entrepreneurship Theory \& Practice, Vol. 20, pp. 25-40.

Cable, D.M., and S. Shane (1997), “A Prisoner's Dilemma Approach to Entrepreneur Venture Capitalist Relationships”, Academy of Management Review, Vol. 22, pp. 142-176.

Caliendo, M., Fossen, F., and Kritikos, A. (2012), "Trust, positive reciprocity, and negative reciprocity: Do these traits impact entrepreneurial dynamics?" Journal of Economic Psychology, Vol. 3 No. 2, pp. 394-409.

Carland, J., Hoy, F., Boulton, W., and Carland, J. (1984), "Differentiating entrepreneurs from small business owners: A conceptualization", Academy of Management Journal, Vol. 9 No. 2, pp. 354-359.

Casillas, J. C, and Acedo, F. J. (2013), "Speed in the Internationalization Process of the Firm”, International Journal of Management Review, Vol. 15, pp. 15-29.

Cassar, G. (2006), "Entrepreneur opportunity costs and intended venture growth", Journal of Business Venturing, Vol. 21, pp. 610-632.

Cassar, G. (2007), "Money, money, money? A longitudinal investigation of entrepreneur career, growth preferences, and achieved growth", Entrepreneurship and Regional Development, Vol. 19 No. 1, pp. 89-107. 
Child, J., and Hsieh, L. H. Y. (2014), "Decision mode, information and network attachement in the internationalization of SMEs: A configurational and contingency analysis", Journal of World Business, Vol. 49, pp. 598-610.

Child, J., Hsieh, L., Elbanna, S., Karmowska, J., Marinova, S., Puthusserry, P., and Zhang, Y. (2017), "SME international business models: The role of context and experience", Journal of World Business, Vol. 52 No. 5, pp. 664-679.

Chudzikowski, K., Fink, G., Mayrhofer, W., and Migliore, L. (2011), "Relation between big five personality traits and Hofstede's cultural dimensions: Samples from the USA and India", Cross Cultural Management: An International Journal, Vol. 18 No. 1, pp. 38-54.

Coff, R., and Kryscynski, D. (2011), "Invited editorial: Drilling for micro-foundations of human capital-based competitive advantages", Journal of Management, Vol. 37, pp. 14291443.

Cooper, A. (1993), "Challenges in predicting new firm performance”, Journal of Business Venturing, Vol. 8, pp. 241-253.

Cropanzano, R., and Mitchell, M.S. (2005), "Social exchange theory: An interdisciplinary review", Journal of Management, Vol. 31 No. 6, pp. 874-900.

Cyert, R.M., and March, J.G. (1963), “A behavioral theory of the firm”, Englewood Cliffs, NJ, Vol. 2 No. 4, pp. 169-187.

Czinkota, M. R. and Ronkainen, I. (2006) International Marketing. 8th edn. Cengage Learning.

Davidsson, P. (1991), “Continued entrepreneurship: Ability, need, and opportunity as determinants of small firm growth", Journal of Business Venturing, Vol. 6 No. 6, pp. $405-$ 429.

Davidsson, P., Delmar, F., and Wiklund, J. (2006), Entrepreneurship and the Growth of Firms. Edward Elgar, Cheltenham.

De Clercq, D., Sapienza, H. J., Yavuz, R. I., and Zhou, L. (2012), “Learning and Knowledge in early internationalization research: Past accomplishments and future direction", Journal of Business Venturing, Vol. 27, pp. 143-165

Dimitratos, P., Petrou, A., Plakoyiannaki, E., and Johnson, J.E. (2011), "Strategic decisionmaking processes in internationalization: Does national culture of the focal firm matter?" Journal of World Business, Vol. 46 No. 2, pp. 194-204.

Dutta, D., and Thornhill, S. (2008), “The evolution of growth intentions: Toward a cognitionbased model", Journal of Business Venturing, Vol. 23 No. 3, pp. 307-332. 
El Shoubaki, A., Laguir, I., and den Besten, M. (2019), "Human capital and SME growth: The mediating role of reasons to start a business", Small Business Economics, 2019, pp. 1-15.

Evans, K.M., Ermilina, V., and Salaiz, A. (2020), “The role of reciprocity in the internationalization of social enterprises", Cross Cultural \& Strategic Management, Vol. 27 No. 1, pp. 75-91.

Felin, T., Foss, N.J., and Ployhart, R.E (2015), “The microfoundations movement in strategy and organization theory", The Academy of Management Annals, Vol. 9 No. 1, pp. 575-632.

Geh, E. (2010), "Understanding the antecedents to an entrepreneurial firm's intent to engage in international strategic alliances”, Journal of Enterprising Culture, Vol. 18 No. 4, pp. 419-33.

Gouldner, A.W. (1960), “The norm of reciprocity: A preliminary statement”, American Sociological Review, pp. 61-178.

Gundlach, S., and Sammartino, A. (2020), “Are international small business owners really that different?” Cross Cultural \& Strategic Management, Vol. 27 No.1, pp. 92-117.

Guzmán, J., and Santos, F.J. (2001), "The booster function and the entrepreneurial quality: An application to the province of Seville", Entrepreneurship \& Regional Development, Vol. 13, pp. 211-228.

Haapanen, L., Hurmelinna-Laukkanen, P., and Puumalainen, K. (2020), "When strategic consensus matters: Dynamic managerial capabilities and firm internationalization as seen by TMT", Cross Cultural \& Strategic Management, forthcoming.

Hambrick, D.C., and Mason, P.A. (1984), "Upper echelons: The organization as a reflection of its top managers", Academy of Management Review, Vol. 9 No. 2, pp. 193-206.

Hamelin, A. (2013), "Influence of family ownership on small business growth. Evidence from French SMEs", Small Business Economics, Vol. 41 No. 3, pp. 563-579.

Handrito, R.P., Slabbinck, H., and Vanderstraeten, J. (2020), "Enjoying or Refraining from Risk? The Impact of Implicit Need for Achievement and Risk Perception on SME Internationalization", Cross Cultural \& Strategic Management, forthcoming

Hermans, J., Slabbinck, H., Vanderstraeten, J., Brassey, J., Dejardin, M., Ramdani, D., and van Witteloostuijn, A. (2017), “The power paradox: Implicit and explicit power motives, and the importance attached to prosocial organizational goals in SMEs", Sustainability, Vol. 9 No. 11, 2001.

Herron, L., and Robinson, R. (1993), “A structural model of the effects of entrepreneurial characteristics on venture performance", Journal of Business Venturing, Vol. 8 No. 3, pp. 281-294. 
Hofstede, G. (1991), Organizations and cultures: Software of the mind. McGrawHill, New York.

Hollensen, S. (2014) Global Marketing. Europe: Prentice Hall.

Holmquist, C., and Carter, S. (2009), “The Diana project: pioneering women studying pioneering women”, Small Business Economics, Vol. 32 No. 2, pp. 121-128.

Hurst, E., and Pugsley, B.W. (2011), “What do small businesses do?” Brookings Papers on Economic Activity, Economic Studies Program, The Brookings Institution, Vol. 43 No. 2 (No. w17041), pp. 73-142.

Hutchinson, K., Quinn, B., and Alexander, N. (2006), "The role of management characteristics in the internationalisation of SMEs: Evidence from the UK retail sector", Journal of Small Business and Enterprise Development, Vol. 13 No. 4, pp. 513-534.

Hutzschenreuter, T., and Horstkotte, J. (2013), "Performance effects of international expansion processes: The moderating role of top management team experiences", International Business Review, Vol. 22 No. 1, pp. 259-277.

Janjuha-Jivraj, S., and Spence, L.J. (2009), "The nature of reciprocity in family firm succession”, International Small Business Journal, Vol. 27 No. 6, pp. 702-719.

Johanson, J., and Vahlne, J.E. (1977), “The internationalization process of the firm-a model of knowledge development and increasing foreign market commitments", Journal of International Business Studies, Vol. 8 No. 1, pp. 23-32.

Johanson, J. and Vahlne, J.E. (2009), “The Uppsala internationalization process model revisited: From liability of foreignness to liability of outsidership”, Journal of International Business Studies, Vol. 40 No. 9, pp. 1411-1431.

Jones, M.V., and Coviello, N.E. (2005), "Internationalisation: Conceptualising an Entrepreneurial Process of Behavior in Time", Journal of International Business Studies, Vol. 36 No. 3, pp. 284-303.

Jones, M. V., Coviello, N., and Tang, Y. K. (2011), “International Entrepreneurship research (1989-2009): A domain ontology and thematic analysis", Journal of Business Venturing, Vol. 26, pp. 632-659.

Jung, D.I., Ehrlich, S.B., De Noble, A.F., and Baik, K.B. (2001), "Entrepreneurial selfEfficacy and its relationship to entrepreneurial action: A comparative study between the US and Korea”, Management International, Vol. 6 No. 1, pp. 41-54.

Kalinic, I., and Pater, M. (2013), "Explaining mechanisms of social entrepreneurs internationalization: Concept of social cosmopreneur", Academy of Management Proceedings, Vol. 2013 No. 1, pp. 15625. 
Keupp, M. M., and Gassmann, O. (2009), “The Past and Future of International Entrepreneurship: A Review and Suggestions for Developing the Field", Journal of Management, Vol. 35 No.3, pp. 600-633.

Kim, P.H., and Aldrich, H.E. (2005), "Social capital and entrepreneurship”, Foundations and Trends in Entrepreneurship, Vol. 1 No. 2, pp. 55-104.

Kiss, A. N., Danis, W.M., and Cavusgil, S. T. (2012), "International entrepreneurship research in emerging economies: A critical review and research agenda", Journal of Business Venturing, Vol. 27, pp. 266-290.

Kolvereid, L, and Bullvag, E. (1996), "Growth intentions and actual growth: The impact of entrepreneurial choice”, Journal of Enterprising Culture, Vol. 4 No.1, pp. 1-17.

Kolvereid, L. (2002), “Growth aspiration among Norwegian entrepreneurs”, Journal of Business Venturing, Vol.7 No. 3, pp. 209-222.

Lee, D.Y., and Tsang, E.W. (2001), "The effects of entrepreneurial personality, background and network activities on venture growth", Journal of Management Studies, Vol. 38, pp. 583-602.

Leung, K., and Bond, M.H. (1989), "On the empirical identification of dimensions for crosscultural comparisons”, Journal of Cross-Cultural Psychology, Vol. 20, pp. 133-151.

Liñán, F., and Chen, Y.W. (2009), "Development and Cross-Cultural application of a specific instrument to measure entrepreneurial intentions", Entrepreneurship Theory \& Practice, Vol. 33, pp. 593-617.

Mair, J., and Marti, I. (2006), "Social entrepreneurship research: A source of explanation, prediction, and delight", Journal of World Business, Vol. 41 No. 1, pp. 36-44.

Mejri, K., and Umemoto, K. (2010), “Small- and Medium-sized enterprise internationalization: Towards the knowledge-based model", Journal of International Entrepreneurship, Vol. 8, pp. 156-167.

Miner, J., Smith, N., and Bracker, J. (1989), "Role of entrepreneurial task motivation in the growth of technologically innovative firms", Journal of Applied Psychology, Vol. 74 No. 4, pp. 554-560.

Oviatt, B.M., and McDougall, P.P. (1994), "Toward a theory of international new ventures", Journal of International Business Studies, Vol. 25, pp. 45-64.

Oviatt, B.M., and McDougall, P.P. (2005), "Defining international entrepreneurship and modeling the speed of internationalization", Entrepreneurship Theory \& Practice, Vol. 29 No. 5, pp. 537-553. 
Penrose, E. (1959). The Theory of the Growth of the Firm. Oxford University Press: Blackwell.

Perksa, K.J., and Hughes, M. (2008), "Entrepreneurial decision-making in internationalization: Propositions from mid-size firms", International Business Review, Vol. 17, pp. 310-330.

Peschken, T., Shukla, P., Lennon, J., and Rate, S. (2016), “The role of information alignment and entrepreneurial traits on SME internationalization: A conceptual framework", Management Research Review, Vol. 39 No. 2, pp. 196-214.

Phan, P., and Wright, M. (2018), “Advancing the science of human cognition and behavior", Academy of Management Perspectives, Vol. 32 No. 2, pp.179-181.

Pinho, J. C. (2007), “The Impact of Ownership: Location-Specific Advantages and Managerial Characteristics on SME Foreign Entry Mode Choices”, International Marketing Review, Vol. 24 No. 6, pp. 715-734.

Powell, T. C., Lovallo, D., and Fox, C. R. (2011), "Behavioral strategy”, Strategic Management Journal, Vol. 32 No. 13, pp. 1369-1386.

Ragin, C. (2014), The comparative method: Moving beyond qualitative and quantitative strategies. University of California Press.

Reuber, A.R., and Fischer, E. (1997), “The influence of the management team's international experience on the internationalization behavior of SMEs", Journal of International Business Studies, Vol. 28, pp. 807-825.

Rialp, A., Rialp, J., and Knight, G.A. (2005), “The phenomenon of early internationalizing firms: What do we know after a decade (1993-2003) of scientific inquiry?” International Business Review, Vol. 14, pp. 147-166.

Ruzzier, M., Antoncic, B., Hisrich, R.D., and Konecnik, M. (2007), "Human capital and SME internationalization: A structural equation modelling study", Canadian Journal of Administrative Sciences, Vol. 24 No. 1, pp. 15-29.

Schultheiss, O., and Brunstein, J.C. (2010), Implicit Motives (O.C. Schultheiss \& J.C. Brunstein Eds.). New York: Oxford.

Schumpeter, J. (1912/1988) Theorie der wirtschaftlichen Entwicklung. Berlin: Duncker and Humblot.

Sharir, M., and Lerner, M. (2006), "Gauging the success of social ventures initiated by individual social entrepreneurs", Journal of World Business, Vol. 41 No. 1, pp. 6-20.

Shepherd, D. A. (2011), “Multi-Level Entrepreneurship Research: Opportunities for Studying Entrepreneurial Decision Making”, Journal of Management, Vol. 37 No. 2, pp. 412-420. 
Shrader, R.C., Oviatt, B.M., and McDougall, P.P. (2000), "How new ventures exploit tradeoffs among international risk factors: Lesson for the accelerated internationalization of the 21st century", Academy of Management Journal, Vol. 43 No. 6, pp. 1227-1247.

Siepel, J., Camerani, R., and Masucci, M. (2019), "Skills combinations and firm performance", Small Business Economics, 2019, pp. 1-23.

Slabbinck, H., van Witteloostuijn, A., Hermans, J., Vanderstraeten, J., Dejardin, M., Brassey, J., and Ramdani, D. (2018), "The added value of implicit motives for management research Development and first validation of a Brief Implicit Association Test (BIAT) for the measurement of implicit motives", PloS ONE, Vol. 13 No. 6, 2018.

Stam, E., and Wennberg, K. (2009), “The roles of R\&D in new firm growth”, Small Business Economics, Vol. 33, pp. 77-89.

Teece, D.J. (2007), "Explicating dynamic capabilities: the nature and microfoundations of (sustainable) enterprise performance", Strategic Management Journal, Vol. 28 No. 13, pp. 1319-1350.

Terjesen, S., and Elam, A. B. (2009), “A development and test of practice theory to explore transnational entrepreneurs' venture internationalization", Entrepreneurship Theory \& Practice, Vol. 33, pp. 1093-1120.

Terjesen, S., Hessels, J., and Li, D. (2016), “Comparative International Entrepreneurship: A Review and Research Agenda”, Journal of Management, Vol. 42 No. 1, pp. 299-344.

Thomas, A.S., and Mueller, S.L. (2000), “A case for comparative entrepreneurship: Assessing the relevance of culture", Journal of International Business Studies, Vol. 31 No. 2, pp. 287-301.

Uzzi, B. (1997), "Social structure and competition in interfirm networks: The paradox of embeddedness", Administrative Science Quarterly, pp. 35-67.

Vahlne, J. E., and Johanson, J. (2013), “The Uppsala model on evolution of the multinational business enterprise-from internalization to coordination of networks", International Marketing Review, Vol. 30 No. 3, pp. 189-210.

Vahlne, J. E., and Johanson, J. (2017), "From internationalization to evolution: The Uppsala model at 40 years”, Journal of International Business Studies, Vol. 48 No. 9, pp. 10871102.

Verheul, I., and Van Mil, L. (2011), "What determines the growth ambition of Dutch earlystage entrepreneurs?” International Journal of Entrepreneurial Venturing, Vol. 3, pp. 183 207. 
Verver, M., and Koning, J. (2018), “Toward a kinship perspective on entrepreneurship", Entrepreneurship Theory \& Practice, Vol. 42 No. 4, pp. 631-666.

Welch, C.L., Welch, D.E., and Hewerdine, L. (2008), “Gender and export behaviour: Evidence from women-owned enterprises", Journal of Business Ethics, Vol. 83 No. 1, pp. 113-126.

Wijbenga, F. H., and van Witteloostuijn, A. (2007), "Entrepreneurial locus of control and competitive strategies-The moderating effect of environmental dynamism", Journal of Economic Psychology, Vol. 28 No. 5, pp. 566-589.

Wiklund, J., Davidsson, P., and Delmar, F. (2003), "What do they think and feel about growth? An expectancy-value approach to small business managers' attitudes toward growth", Entrepreneurship Theory \& Practice, Vol. 27 No. 3, pp. 247-270.

Wiklund, J., and Shepherd, D. (2003), “Aspiring for, and achieving growth: The moderating role of resources and opportunities”, Journal of Management Studies, Vol. 40, pp. 19191941.

Woldesenbet, K., Ram, M., and Jones, T. (2012), “Supplying large firms: The role of entrepreneurial and dynamic capabilities in small businesses", International Small Business Journal, Vol. 30 No. 5, pp. 493-512.

Zhao, H., Seibert, S.E., and Lumpkin, G.T. (2010), “The relationship of personality to entrepreneurial intentions and performance: A meta-analytic review", Journal of Management, Vol. 36, pp. 381-404.

Zucchella, A., Palamara, G., and Denicolai, S. (2007),k "The drivers of the early internationalization of the firm", Journal of World Business, Vol. 42, pp. 268-280. 
Table 1: Contributions to the Special Section

\begin{tabular}{|c|c|c|c|c|c|c|}
\hline Title and author(s) & Focus & Research question & Theory applied & Method & Data & Main contribution \\
\hline $\begin{array}{l}\text { Motives to SME } \\
\text { Internationalization: A } \\
\text { comparative study of } \\
\text { export propensity } \\
\text { among food and drink } \\
\text { SMEs in Wales and } \\
\text { Brittany } \\
\text { Author: R. Bowen }\end{array}$ & $\begin{array}{l}\text { Pre- } \\
\text { internationalization: } \\
\text { Exporting or not }\end{array}$ & $\begin{array}{l}\text { How do entrepreneurial, } \\
\text { firm and environmental } \\
\text { characteristics influence } \\
\text { the attitudes towards and } \\
\text { motives to } \\
\text { internationalize }\end{array}$ & $\begin{array}{l}\text { Contingency } \\
\text { Theory (although } \\
\text { not explicitly } \\
\text { positioned as } \\
\text { such) }\end{array}$ & $\begin{array}{l}\text { Mixed-method: } \\
\text { Empirical- } \\
\text { quantitative } \\
\text { (logistic } \\
\text { regressions) and } \\
\text { Empirical- } \\
\text { qualitative (in- } \\
\text { depth interviews) }\end{array}$ & $\begin{array}{l}\text { - Questionnaire to } \\
169 \text { food and drink } \\
\text { producing SMEs in } \\
\text { Wales and Brittany } \\
\text { - Semi-structured } \\
\text { follow-up } \\
\text { interviews with } 37 \\
\text { food and drink } \\
\text { producing SMEs in } \\
\text { Wales and Brittany }\end{array}$ & $\begin{array}{l}\text { - Stresses that exporters' motives } \\
\text { and attitudes to internationalize } \\
\text { and those of non-exporters are not } \\
\text { symmetrical } \\
\text { - Acknowledges that to } \\
\text { understand the underlying } \\
\text { motives and attitudes to } \\
\text { internationalization, insights into } \\
\text { a complex web of entrepreneurial, } \\
\text { firm and environmental } \\
\text { antecedents is needed }\end{array}$ \\
\hline $\begin{array}{l}\text { The role of reciprocity } \\
\text { in the } \\
\text { internationalization of } \\
\text { social enterprises } \\
\text { Authors: Evans, K.M.; } \\
\text { Ermilina, V., and } \\
\text { Salaiz, A. }\end{array}$ & $\begin{array}{l}\text { Internationalization } \\
\text { behaviour } \\
\text { (conceptual) }\end{array}$ & $\begin{array}{l}\text { How does } \\
\text { internationalization occur } \\
\text { within social enterprises, } \\
\text { what is the role of } \\
\text { reciprocity? }\end{array}$ & $\begin{array}{l}\text { Social Exchange } \\
\text { Theory } \\
\text { (Gouldner, 1960) }\end{array}$ & Conceptual & $\begin{array}{l}\text { Conceptual, } \\
\text { supported by two } \\
\text { illustrative cases }\end{array}$ & $\begin{array}{l}\text { Conceptualization of a firm's } \\
\text { social mission as a valuable } \\
\text { intangible asset that can enhance } \\
\text { performance outcomes (i.e. } \\
\text { internationalization), through } \\
\text { reciprocity }\end{array}$ \\
\hline $\begin{array}{l}\text { Are international small } \\
\text { business owners really } \\
\text { that different? } \\
\text { Authors: Gundlach, S. } \\
\text { and Sammartino, A. }\end{array}$ & $\begin{array}{l}\text { Pre- } \\
\text { internationalization: } \\
\text { Internationalizing or } \\
\text { not }\end{array}$ & $\begin{array}{l}\text { Do female small business } \\
\text { owners have different } \\
\text { personality traits than } \\
\text { their decision-making } \\
\text { employee counterparts, } \\
\text { and do they assess their } \\
\text { capabilities differently? } \\
\text { Are there any differences } \\
\text { in relation to the } \\
\text { propensity to } \\
\text { internationalize and the } \\
\text { perceived barriers to } \\
\text { internationalization? }\end{array}$ & $\begin{array}{l}\text { No specific } \\
\text { theory, but the } \\
\text { ideas originate } \\
\text { from Female } \\
\text { Entrepreneurship }\end{array}$ & $\begin{array}{l}\text { Empirical- } \\
\text { quantitative } \\
\text { (independent } \\
\text { samples } t \text {-tests) }\end{array}$ & $\begin{array}{l}\text { Questionnaire to } \\
186 \text { female } \\
\text { entrepreneurs } \\
\text { (business owners) } \\
\text { and } 137 \text { female } \\
\text { decision-making } \\
\text { employees }\end{array}$ & $\begin{array}{l}\text { - For female entrepreneurs, no } \\
\text { statistical difference between } \\
\text { internationalizing and non- } \\
\text { internationalizing business owners } \\
\text { on the typical "male" individual } \\
\text { traits and attributes could be } \\
\text { found. This seems to suggest that } \\
\text { for this entrepreneur segment, } \\
\text { other individual constructs lie at } \\
\text { the basis of the decision to } \\
\text { internationalize. } \\
\text { - For female entrepreneurs, } \\
\text { perceived political and financial } \\
\text { barriers, but also personal barriers } \\
\text { seem to lie at the basis of the } \\
\text { decision to internationalize. }\end{array}$ \\
\hline
\end{tabular}


When strategic

consensus matters:

Dynamic managerial

capabilities and firm

internationalization as

seen by TMT

Authors: Haapanen, L.;

Hurmelinna-

Laukkanen, P., and

Puumalainen, $\mathrm{K}$.
- Internationalization behaviour: Deliberate country expansion

(strategy) (yes/no)

- Internationalization

performance: Foreign

customers (yes/no);

recurring foreign

customers (yes/no);

long-term

international

customers (yes/no)
How do dynamic - Dynamic Empirical- Questionnaire to

managerial capabilities

and TMT strategic

consensus jointly

influence firm

internationalization?

(2)

managerial quantitative 261 TMT members

capabilities

(Qualitativ

(Augier and Comparative

Teece, 2009)

Analysis)

- Upper echelon

theory (Hambrick

and Mason, 1984) in 61 firms

internationalization by bringing

together manager- and team-level characteristics in a configurational approach 